\title{
Examining The Relationship Between Diversity And Firm Performance
}

\author{
Byron J. Hollowell, (E-mail: bjh28@psu.edu), Pennsylvania State University
}

\begin{abstract}
There is a heated debate taking place in the between those who think firms should be more diverse because it is the right thing to do and those who think firms should be more diverse because it actually enhances shareholder value. This study establishes a solid business case for managing diversity as a bottom line initiative. I find a positive and significant relationship between firm diversity and long-term firm performance. These findings forecast an increase in the employment opportunities for educators, students and recent graduates from diverse backgrounds.
\end{abstract}

\section{INTRODUCTION}

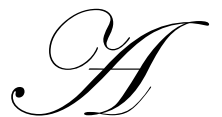

successful, multi-national corporation must create an inclusive corporate culture that recognizes the unique contributions of employee regardless of their ethnicity or country of origin. This is no morality play. If they are to survive, international companies must be innovative and efficient in their management of diverse employees and heterogeneous market segments (Richard, McMillan, Chadwick \& Dwyer, 2003; Gomez-Mejia \& Palich, 1999). Domestic corporations have been forced to reexamine their diversity management practices in the face of international competition and the growing levels of diversity in the employment market. A study by the Hudson Institute forecasted that the number of White non-Hispanics, as a percentage of the total United States workforce, will continue to rapidly decline (Judy \& D'Amico, 1997). Kim (2003) expects a significant increase in the number of Hispanic workers because of robust immigration and birth rate gains. These changing demographics emphasize the importance of examining workforce diversity.

The most frequently asked question by executives about workforce diversity is how it affects firm performance (Carter, Simkins \& Simpson, 2003). Whereas, extensive empirical research has examined the role of diversity as it relates to age, tenure and product mix (Chatman, Polzer, Barsade \& Neale, 1998; Gomez-Mejia \& Palich, 1999; Richard, 2000), there has been little research involving an empirical study that examines diversity and long-term stock price performance. The current study seeks to fill this void by examining the 4 year relationship between diversity and shareholder wealth for a sample of firms who have been identified as diversity leaders from among the Fortune 500. I define diversity management as maximizing the unique skills and abilities of each employee in an organization. In particular, diversity management is focused on how an organization recruits, trains, and promotes underrepresented groups in the corporate labor market.

In practice, some firms actively promote workforce diversity, while other firms view diversity initiatives as being expensive. Given the controversy around whether diversity is an essential part of good management practice, the relationship between company diversity and shareholder value deserves both theoretical and empirical investigation. The purpose of this paper is to empirically examine this relationship by studying the Fortune 500's most diverse firms. I measure the portfolio performance of elite diversity management firms against various market benchmarks for a four year period. I find a positive significant relationship between firm diversity and firm value. For example, if an investor formed a portfolio composed of twenty five of Fortune 500's best diversity practicing firms, the median portfolio 4-year return for $2001-2004$ is $96.78 \%$. This robust return is contrasted with the $4.17 \%$ return for the large capitalization market index over the same period. In other words, every dollar invested in the Fortune diversity portfolio results in a terminal wealth of $\$ 1.97$, while every dollar invested in the market index results in a terminal wealth of $\$ 1.04$. To my knowledge, this finding represents the first empirical evidence that links firm diversity and long-term shareholder value. 
The remainder of the paper is organized as follows. Section 2 presents the theoretical link between diversity, group performance and firm value, and Section 3 discusses the data and methodology employed. The results are discussed in Section 4, while Section 5 concludes.

\section{DIVERSITY, GROUP PERFORMANCE AND FIRM VALUE}

The empirical research presents contradictory findings on the value of diversity. For example, Watson, Kumar and Michaelson (1993) report that homogeneous workgroups are better in the short-term, while heterogeneous workgroups outperform other groups over an extended period of time. However, Pelted, Eisenhardt and Xin (1999) found that diversity in groups resulted in emotional conflict that ultimately harmed task performance. Mixed results about the worth of diversity was further documented in Williams and O'Reilly's (1998) diversity survey that reviewed the diversity literature for the last 40 years and analyzed over 90 separate studies. Of the 90 studies surveyed, $45 \%$ percent of the race and ethnicity studies reported the positive effects of diversity, while $55 \%$ percent of the studies described the negative effects of diversity.

According to Carter, Simkins, and Simpson (2003) the positive effects of racial diversity include increased creativity, enhanced decision making and problem solving, and higher overall performance. Consequently, diversity management will have a positive impact on not only group processes but on firm performance as well. Other studies show that heterogeneity in race is valuable to the firm because it can lead to increased creativity, flexibility, and better decisions making (Elsass \& Graves, 1997; McLeod, Lobel \& Cox, 1996). According to Cox and Blake (1991), firms that can successfully attract a diverse workforce will increase their revenue potential by matching the demographics of the markets they serve. Under this view, looking more like the customer base is thought to enhance marketing opportunities and increase firm value. Furthermore, organizations that develop reputations for managing diversity will likely attract the best minority personnel (Carrell, Elbert \& Hatfield, 2000).

In view of the benefits of diversity outlined above, I formulate the hypothesis -

$H_{o}-A$ higher level of diversity is positively related to long-term firm performance. The subsequent section introduces the data and methodology to test this hypothesis.

\section{DATA AND METHODOLOGY}

\section{Data}

The database used to extract Chief Executive Officer (CEO) remuneration is ExecuComp. The ExecuComp dataset has information on all aspects of compensation for the top five executives at each of the firms in the S\&P 500, S\&P Mid Cap 400 and S\&P Small Cap 600. The 2004 firm specific ExecuComp data are collected directly from the companies' proxy statements filed with the Securities and Exchange Commission.

My data consist of monthly observations of stock returns from The Center for Research in Security Prices (CRSP). The sample period is from January 1, 2001 to December 31, 2004. Hence, stocks that are not on CRSP or ExecuComp over the entire period are not included in the diversity portfolio. In addition, six of the top 25 diversity firms from the Fortune 2006 list are private companies with no firm data publicly available.

\section{Methodology}

Two measures are used to evaluate the long-run performance of a firm. 4 year cumulative average adjusted returns (CAR) are calculated in excess of the market benchmark and 4-year buy and hold returns are calculated for both sample firms and the market index. The methodology used in this paper is similar to that used in other studies of long-term returns (Rauterkus \& Song, 2005; Barber \& Lyon, 1997). Monthly market-adjusted returns are calculated as the monthly raw return on a stock minus the monthly benchmark market return for the corresponding 21-trading day period. 
Fama (1998) documents long-term return estimation is often sensitive to methodology choice. To avoid this bias, sensitivities are run on the market benchmark. The market benchmark includes (1) an index comprised of the large stock market index, and (2) the CRSP value-weighted index. Canina, Michaely, Thaler, and Womack (1998) observed that the equally-weighted CRSP index results in an upward overestimation of long-term returns. Therefore, I employ the value-weighted index to avoid this inherent bias. The benchmark-adjusted return $\left(\mathrm{ar}_{\mathrm{it}}\right)$ for stock $i$ in event month $t$ is calculated for the event firm for 48 months

(1) $\operatorname{ar}_{\mathrm{it}}=\mathrm{r}_{\mathrm{it}}-\mathrm{r}_{\mathrm{L}}$

(2) $\mathrm{ar}_{\mathrm{it}}=\mathrm{r}_{\mathrm{it}}-\mathrm{r}_{\mathrm{VW}}$

where $\mathrm{r}_{\text {it }}$ is the stock return for event firm $i$ in month $t, \mathrm{r}_{\mathrm{L}}$ is an index comprised of large stocks and $\mathrm{r}_{\mathrm{Vw}}$ is the valueweighted index from CRSP.

The average benchmark-adjusted return on a portfolio of $n$ stocks for even month $t$ is the equal-weighted average of the benchmark adjusted returns for

( 4 ) $\operatorname{ẠR}_{\mathrm{t}}=1 / \mathrm{N} \sum_{i=1}^{N} \mathrm{ar}_{\text {it }}$

where $\mathrm{N}$ is the number of firms.

The cumulative benchmark-adjusted aftermarket performance (CAR) from event month $q$ to event month $s$, where $q$ is January of the event year and $s$ is December is represented by equation

( 5 ) $\mathrm{CAR}_{\mathrm{q}, \mathrm{s}}=\sum_{t=q}^{s} \stackrel{\mathrm{A} \mathrm{R}_{\mathrm{t}}}{ }$

As an alternative to the CAR, which implicitly assumes monthly portfolio rebalancing, a forty-eight month holding period return, $\mathrm{R}_{\mathrm{i}}$, for firm $i$ is calculated as

( 6 ) $\mathrm{R}_{\mathrm{i}}=\prod_{t=1}^{36}\left(1+\mathrm{r}_{\mathrm{it}}\right)-1$

This equation measures the total return from a buy and hold strategy where a stock is purchased at the closing market price in January 2001 and held for a four-year period. To interpret this four year total return, I compute the buy and hold excess returns (BHER) for firm $i$ as

\section{( 7 ) $\mathrm{BHER}_{\mathrm{i}}=\mathrm{R}_{\mathrm{i}}-\mathrm{R}_{\mathrm{mkt}}$}

where $\mathrm{R}_{\mathrm{i}}$ is the holding period return for $\$ 1$ invested in a portfolio of Fortune top diverse firms and $\mathrm{r}$ mkt is the holding period return for $\$ 1$ invested in the market portfolio. A BHER that is greater than 0 is interpreted as a portfolio of diverse firms outperforming the market and a BHER of less than 0 indicates diversity firms underperformed.

\section{RESULTS}

Table 1 presents the descriptive statistics from ten of the nation's top diversity companies. Fortune annually identifies the top diversity firms from among their Fortune 500 peers (Roth, 2006). Fortune formulates an overall diversity ranking based on minority representation on the corporate board, minority representatives among corporate officers, percentage spent with minority-owned suppliers and percentage of contributors that benefit minorities. The top ten diversity leading firms average: 11,375 employees, $47 \%$ minorities, $42 \%$ women, 52 hours of professional training, $\$ 82,002$ salaried annual pay and $\$ 40,237$ hourly annual pay. The top diversity firm, Genentech, has 8,121 
employees. In addition, approximately $42 \%$ of Genentech's employees are minorities and $50 \%$ are women. The firms supplies over 51 hours of professional training per year on each employee. Finally, Genentech's average salaried annual pay is $\$ 69,425$ and $\$ 47,817$ for hourly employees.

Table 2 provides an overview of what makes the top 10 firms on the Fortune diversity list unique. The top diversity firm, Genentech, rewards their employees by administering a generous employee stock ownership program. In fact, $95 \%$ of Genentech's employees are shareholders. In addition, Valero Energy donated over \$1 million dollars along with semi-trailers of supply to the Katrina and Rita Hurricane relief. Tom Mendoza, the CEO of Network Appliance, makes 15 to 20 calls a week to thank employees for outstanding performance.

Table 3 reports the operating descriptive statistics for the most diverse companies from the 2006 Fortune survey. Data is extracted from the ExecuComp database. Fourteen of the top diversity firms have firm data available. In 2004, the average operating figures are: sales of $\$ 13$ million, 5 year sales growth average of $17 \%$, net income of $\$ 1.5$ million, ROE of $17.6 \%$ and average assets of $\$ 30.7$ million. Nordstrom is the top performing company as measured by sales and ROE. In 2004, Nordstrom reported sales of $\$ 7.3$ million, net income of $\$ 393.5$ thousand, net income 5 year growth of $17.8 \%$, ROE of $22 \%$ and average assets of $\$ 4.6$ million.

Table 4 reports the CEO compensation for fourteen of the top twenty five diversity firms that have 2004 ExecuComp remuneration data available. The average CEO salary components are: $\$ 4$ million in yearly cash pay, $\$ 1.98$ million in yearly bonus pay, and $\$ 16.7$ million in total pay. The highest paid CEO is Mr. Jacobs of QUALCOMM. Mr. Jacobs enjoyed a 2004 pay package of \$1 million in cash, \$1.7 million in bonuses, and an additional \$44.4 million in options if all stock option grants are valued.

Table 5 reports the average market-adjusted returns (AR) and cumulative large stock (S\&P 500) adjusted returns (CAR) for the years 2001-2004. The total average adjusted return for the sixteen publicly traded diversity leading stocks is $154 \%$ for 4 years or $38.5 \%$ on an annual basis. The S\&P 500 market index averaged $6.12 \%$ over the same 4 year time period. Therefore, the total market adjusted return (raw return - market return) for the four year period was $147.88 \%$ or $36.97 \%$ on an annual basis.

The poor performance of the large stock index is strongly influenced by the bull market experienced from September 2001 to December 2002. During the $3^{\text {rd }}$ quarter 2001, dismal labor and retail numbers pushed the stock market into a correction. A market correction is typically defined as a drop in market levels of at least $10 \%$, but not more than 20\%. By September 17, 2001, the first day of trading after the September 11 attacks, the Dow Jones Industrial Average dropped 684.81 points to 8,921. That loss officially pushed the Dow into a bear market, which lasted until December 2002. Shortly thereafter, the stock market downturn of 2002 pushed the Dow and NASDAQ from 10,000 and 2,000 levels in March, respectively, to five- and six- year lows of 7,200 and 1,100 by October 2002.

The measurement of the long-run performance of stocks is especially sensitive to the benchmark employed. This is not unusual in event studies using long windows, as indicated by Dimson and Marsh (1986). Table 6 reports the average matching firm-adjusted returns and cumulative average value weighted market adjusted returns for the 48 months after January 1, 2001. The total average return for all sixteen diversity leading firms is $154 \%$ for 4 years or $38.5 \%$ on an annual basis. The value weighted market index averaged $24.73 \%$ over the same 4 year period. Therefore, the total market adjusted return (raw return - market return) for the four year period was $129.27 \%$ or $32.32 \%$ on an annual basis. My results confirm a slight upward bias in the non-value weighted index first reported by Canina, Michaely, Thaler, and Womack (1998). However, the positive excess returns remain regardless of market benchmark used.

Table 7 reports the 4-year holding period returns for a portfolio invested in 16 of the Fortune top 25 most diverse companies. The top diversity portfolio is compared with two separate specifications of the market index. The median diversity portfolio 4-year return is $96.78 \%$ contrasted with $4.17 \%$ for the large cap market index, and $-0.03 \%$ for the value-weighted market index. In other words, every dollar invested in a 4 year portfolio containing Fortune 500 's most diverse firms, results in a terminal wealth of $\$ 1.97$, while every dollar invested in the large cap market index and the value weighted market index results in a terminal wealth of $\$ 1.04$ and $\$ 0.99$ respectively. 


\section{CONCLUSION}

This paper documents a strategy of investing in a portfolio of top diversity companies, which would have left an investor with $\$ 1.93$ versus just $\$ 1.04$ for each dollar invested in the large capitalization market index from 2001 to 2004. In the long run, the Fortune top diversity firm portfolio outperformed the market. My results present some of the first empirical evidence that links firm diversity with multiple year shareholder value.

Why does diversity management positively affect the bottom line? The conceptual literature provides several plausible explanations (Cox \& Blake, 1991; Robinson \& Dechant, 1997). First, diversity increases ingenuity and innovation. According to this view, attitudes and beliefs vary in tandem with demographics variables such as age, race, and gender. Finally, diversity encourages more effective problem-solving. While heterogeneity may initially produce less cohesion in the decision making process, the variety of outlooks that emerges from a diverse group causes managers to consider more perspectives and therefore leads to more informed decision making in the long run.

\section{REFERENCES}

1. Barber, B. and Lyon, J. (1997). Detecting long-horizon abnormal stock returns: the empirical power and specification of test statistics. Journal of Financial Economics. 52. 875-883.

2. Canina, L., Michaely, R., Thaler, R., and Womack, K. (1998). Caveat compounder: a warning about using the daily CRSP equal-weighted index to compute long-run excess returns. The Journal of Finance. 73, 110140.

3. Carrel, M., Elbert, N., and Hatfield, R. (2000). Human Resource Management: Strategies for Managing a Diverse and Global Workforce, $6^{\text {th }}$ Ed. Dryden/Harcourt College Publishers.

4. Carter, D., Simkins,B., and Simpson, W. (2003). Corporate Governance, Board Diversity, and Firm Value. The Financial Review 38 (1), 33-53.

5. Chatman, J., Polzer, J., Barsade, S., and Neale, M. (1998). Being different yet feeling similar: The influence of demographic composition and organizational culture on work processes and outcomes. Administrative Science Quarterly. 43, 749-780.

6. Cox, T. J. and Blake, S. (1991). Managing cultural diversity: Implications for organizational competitiveness. Academy of Management Executive. 5(3), 45-55.

7. Dimson, E. and Marsh, P. (1986). Event Study Methodologies and the Size Effect: The Case of UK Press Recommendations. Journal of Financial Economics. 17(1), 1-29.

8. Elsass, P. M. and Graves, L. M. (1997). Demographic diversity in decision-making groups: The experiences of women and people of color. Academy of Management Review. 22, 946-973.

9. Fama, E., (1998). Market efficiency, long-term returns, and behavioral finance. Journal of Financial Economics. 49, 283-306.

10. Gomez-Mejia, L. and Palich, L. (1999). A theory of global strategy and firm efficiencies: Considering the effects of cultural diversity. Journal of Management. Vol 25 (4), 587-606.

11. Judy, R. W. and D'Amico, C. (1997). Workforce 2020: Work and workers in the 21 st century. Indianapolis, IN: Hudson Institute.

12. Kim, J. (2003). Returns of College Education: An Analysis of Hispanic Workers. Journal of Hispanic Higher Education. 2, (3), 276-291.

13. McLeod, P. L., Lobel, S. A., and Cox, T. H. (1996). Ethnic diversity and creativity in small groups. Small Group Research. 27, 248-265.

14. Pelted, L. H., Eisenhardt, K. M., and Xin, K. R. (1999). Exploring the black box: An analysis of work group diversity, conflict, and performance. Administrative Science Quarterly. 44, 128-138.

15. Rauterkus, S. and Song, K. (2005). Auditor's reputation and equity offerings: the case of Arthur Andersen. Financial Management. 34. 121-135.

16. Richard, O. (2000). Racial diversity, business strategy, and firm performance: A resource-based view. Academy of Management Journal. 43(2), 164-177.

17. Richard, O., McMillan, A., Chadwick, K., and Dwyer, S., (2003). Employing an innovation strategy in racially diverse workforces. Group and Organization Management. 28 (1), 107-126. 
18. Robinson, G. and Dechant, K. (1997). Building a business case for diversity. Academy of Management Executive, 11, 21-30.

19. Roth, D. (2006). Fortune's top 25 diversity companies. Fortune Magazine. January 2006.

20. Watson, W. E., Kumar, K., and Michaelson, L. K. (1993). Cultural diversity's impact on interaction process and performance: Comparing homogeneous and diverse task groups. Academy of Management Journal. 36(3), 590-602.

21. Williams, K. and O'Reilly, C., III. (1998). Demography and diversity in organizations: A review of 40 years of research. Research in Organizational Behavior. 20, 77-140.

Table 1

Descriptive Statistics

Top Diversity Companies As Ranked By The Fortune 2006 Survey All Dollars Thousands Unless Otherwise Indicated

\begin{tabular}{|c|c|c|c|c|c|c|c|}
\hline $\begin{array}{l}\text { Diversity } \\
\text { Rank }\end{array}$ & $\begin{array}{l}\text { Company } \\
\text { Name }\end{array}$ & $\begin{array}{c}\text { \# of } \\
\text { Employees }\end{array}$ & $\begin{array}{l}\text { Minority } \\
(\%)\end{array}$ & $\begin{array}{c}\text { Women } \\
(\%)\end{array}$ & $\begin{array}{c}\text { Professional Training } \\
\text { (Hours/Year) }\end{array}$ & $\begin{array}{l}\text { Average } \\
\text { Salary }\end{array}$ & $\begin{array}{c}\text { Average } \\
\text { Hourly Salary }\end{array}$ \\
\hline 1 & Genentech & 8,121 & 42 & 50 & 51 & 69,425 & 47,817 \\
\hline 2 & Valero Energy & 16,582 & 40 & 40 & 67 & 16,651 & 38,227 \\
\hline 4 & Vision Service & 1,915 & 30 & 68 & 40 & 91,699 & 33,993 \\
\hline 5 & Whole Foods & 33,248 & 112 & 45 & 43 & 73,061 & 25,451 \\
\hline 6 & QUALCOMM & 7,562 & 44 & 25 & 20 & 97,456 & 64,792 \\
\hline 7 & Cisco Systems & 26,644 & 42 & 24 & NA & 131,580 & 55,692 \\
\hline 8 & Goldman Sachs & 11,836 & 31 & 38 & 31 & 127,000 & NA \\
\hline 9 & $\begin{array}{l}\text { Network } \\
\text { Appliance }\end{array}$ & 2,712 & 32 & 22 & 66 & 128,317 & 37,260 \\
\hline 10 & $\begin{array}{c}\text { Four Seasons } \\
\text { Average }\end{array}$ & $\begin{array}{c}2,239 \\
\mathbf{1 1}, \mathbf{3 7 3}\end{array}$ & $\begin{array}{l}63 \\
47\end{array}$ & $\begin{array}{l}43 \\
42\end{array}$ & $\begin{array}{l}40 \\
\mathbf{5 2}\end{array}$ & $\begin{array}{l}44,432 \\
\mathbf{8 2 , 0 0 2}\end{array}$ & $\begin{array}{l}29,671 \\
\mathbf{4 0 , 2 3 7}\end{array}$ \\
\hline
\end{tabular}

Table 2

Top Diversity Companies' Unique Company Characteristics As Ranked By The 2006 Fortune Survey

\begin{tabular}{|c|c|c|}
\hline $\begin{array}{l}\text { Diversity } \\
\text { Rank }\end{array}$ & $\begin{array}{c}\text { Diversity } \\
\text { Company Name }\end{array}$ & Company Distinction \\
\hline 1 & Genentech & $95 \%$ of employees are shareholders who have benefited from robust stock gains (up 241\%). \\
\hline 2 & Valero Energy & $\begin{array}{l}\text { Noted for leading edge hurricane Katrina and Rita Relief (over \$1 million donated by } \\
\text { employees). }\end{array}$ \\
\hline 3 & Container Store & Even par-time workers can receive bonuses, and drivers are rewarded for safe driving records. \\
\hline 4 & Vision Service & Not-for-profit insurance firm where managers swap jobs with line workers for a day. \\
\hline 5 & Whole Foods & The stock has almost tripled in value and even part-time workers are eligible for stock options. \\
\hline 6 & QUALCOMM & $\begin{array}{l}\text { All new employees are given stock. Graduate preparation is paid by the company and held on } \\
\text { site. }\end{array}$ \\
\hline 7 & Cisco Systems & $\begin{array}{l}\text { CEO John Chambers stays in touch with employees at monthly breakfast where hard } \\
\text { questions are encouraged from employees. }\end{array}$ \\
\hline 8 & Goldman Sachs & An extensive on-site medical center provides care for all employees and immediate family. \\
\hline 9 & Network Appliance & $\begin{array}{l}\text { President Tom Mendoza makes } 15 \text { to } 20 \text { calls a week to thank employees for outstanding } \\
\text { performance. }\end{array}$ \\
\hline 10 & Four Seasons & All employees can stay for free at any location in the world and meals are discounted by $50 \%$. \\
\hline
\end{tabular}


Table 3

Firm Performance Variables

All Dollars In Thousands Unless Otherwise Indicated. Firms Are Presented Alphabetically

\begin{tabular}{|c|c|c|c|c|c|c|c|}
\hline $\begin{array}{l}\text { Company } \\
\text { Name }\end{array}$ & Industry Description & Sales & $\begin{array}{l}5 \text { Year Sales } \\
\text { Growth }(\%)\end{array}$ & Net Income & $\begin{array}{l}5 \text { Year Net } \\
\text { Income } \\
\text { Growth }(\%)\end{array}$ & ROE (\%) & Assets \\
\hline \multicolumn{8}{|l|}{ American } \\
\hline AFLAC & Life and Health Insurance & 13,275 & 8.0 & 1,299 & 14.5 & 17.15 & 59,326 \\
\hline Amgen & Life and Health Biotech & 10,550 & 27.8 & 2,363 & NA & 11.99 & 29,221 \\
\hline Genentech & Biotech & 4,621 & 27.6 & 785 & NA & 11.57 & 9,403 \\
\hline $\begin{array}{l}\text { Nordstrom } \\
\text { Microsoft }\end{array}$ & Department Stores & 7,304 & 6.5 & 393 & 17.8 & 21.99 & 4,605 \\
\hline Corporation & Information Technology & 36,835 & 12.9 & 8,168 & 1.2 & 10.92 & 92,389 \\
\hline Timberland & Footwear & 1,501 & 9.2 & 153 & 9.6 & 29.85 & 758 \\
\hline \multicolumn{8}{|l|}{ Valero Energy } \\
\hline Corporation & Oil \& Gas & 53,919 & 45.0 & 1,804 & 99.6 & 23.6 & 19,392 \\
\hline QUALCOMM & Communication & 4,800 & 5.4 & 1,720 & NA & 17.85 & 10,820 \\
\hline Whole Foods & Food Retailer & 3,865 & 19.7 & 137 & 33.9 & 13.87 & 1,520 \\
\hline Starbucks & Restaurant & 5,294 & 25.1 & 391 & 33.2 & 15.79 & 3,391 \\
\hline $\begin{array}{l}\text { Corporation } \\
\text { Network }\end{array}$ & Electronics & 5,737 & 14.3 & 241 & 14.8 & 19.45 & 1,521 \\
\hline Appliance & Computer Storage & 1,598 & 17.5 & 226 & 36.7 & 13.59 & 2,373 \\
\hline Average & & 12,934 & 17.1 & 1,532 & 26.9 & 18.0 & 30,718 \\
\hline
\end{tabular}

Table 4

Executive Compensation

All Dollars In Thousands Unless Otherwise Indicated. Firms Are Presented Alphabetically

\begin{tabular}{|c|c|c|c|c|c|c|c|}
\hline Company Name & $\begin{array}{c}\text { CEO } \\
\text { Name }\end{array}$ & $\begin{array}{c}\text { Age } \\
\text { (yrs) }\end{array}$ & Salary & Bonus & Total Pay & Market Value & $\begin{array}{c}\text { \# of } \\
\text { Employees }\end{array}$ \\
\hline AFLAC & Amos & 53 & 1,200 & 2,196 & 8,558 & 20,158 & 6,531 \\
\hline American Express & Chenault & 53 & 1,000 & 6,000 & 19,821 & 70,755 & 77,500 \\
\hline CDW Corporation & Edwardson & 55 & 700 & 1,315 & 6,992 & 5,514 & 3,800 \\
\hline Genentech & Levinson & 54 & 894 & 1,310 & 43,487 & 57,141 & 7,646 \\
\hline Intuit & Bennett & 50 & 990 & 2,560 & 4,885 & 7,172 & 6,700 \\
\hline Microsoft Corporation & Balmer & 48 & 592 & 310 & 911 & 308,296 & 57,000 \\
\hline Network Appliance & Warmenh & 54 & 500 & 543 & 15,637 & 9,765 & 3,801 \\
\hline Nordstrom & Nordstrom & 44 & 44,700 & 1,313 & 2,817 & 6,759 & 49,700 \\
\hline QUALCOMM & Jacobs & 71 & 1,062 & 1,702 & 44,422 & 63,549 & 7,600 \\
\hline Starbucks & Smith & 62 & 1,179 & 2,490 & 27,330 & 18,002 & 96,700 \\
\hline Timberland & Swartz & 45 & 738 & 1,426 & 28,903 & 1,789 & 5,600 \\
\hline Valero Energy Corporation & Greehey & 68 & 1,400 & 2,800 & 22,875 & 11,651 & 19,797 \\
\hline Whole Foods & Mackey & 51 & 342 & 118 & 1,474 & 5,342 & 32,100 \\
\hline Average & & 55 & 4,043 & 1,979 & 16,700 & 42,432 & 27,777 \\
\hline
\end{tabular}


Table 5

Large Capital Market Index Cumulative Average Returns (2001-2004)

All Figures Are In Percentages Unless Otherwise Indicated. Firms Are Presented Alphabetically

\begin{tabular}{cccc}
\hline Company Name & 4 Year Firm Returns & $\begin{array}{c}\text { 4 Year Large Cap Market } \\
\text { Return }\end{array}$ & $\begin{array}{c}\text { 4 Year Excess Returns } \\
\text { (Returns - Valuated) }\end{array}$ \\
\hline AFLAC & 88.91 & 6.12 & 82.79 \\
Amgen & 123.18 & 6.12 & 117.06 \\
CDW & $(96.23)$ & 6.12 & $(102.35)$ \\
Cisco Systems & 9.17 & 6.12 & 3.05 \\
Four Seasons & 144.09 & 6.12 & 137.97 \\
Genentech & 201.63 & 6.12 & 195.51 \\
Intuit & 147.92 & 6.12 & 141.80 \\
Microsoft Corporation & 41.38 & 6.12 & 35.26 \\
Network Appliance & 355.43 & 6.12 & 349.31 \\
Nordstrom & 91.80 & 6.12 & 85.68 \\
QUALCOMM & 408.52 & 6.12 & 402.40 \\
SRA International & 115.64 & 6.12 & 109.52 \\
Starbucks & 204.19 & 6.12 & 198.07 \\
Timberland & 234.20 & 6.12 & 228.08 \\
Valero Energy Corporation & 206.32 & 6.12 & 200.20 \\
Whole Foods & 187.88 & 6.12 & 181.76 \\
Cumulative Average & $\mathbf{1 5 4 . 0 0}$ & & $\mathbf{1 4 7 . 8 8}$ \\
Returns & & & $\mathbf{3 6 . 9 7}$ \\
Annualized Returns & $\mathbf{3 8 . 5 0}$ & & \\
\hline
\end{tabular}

Table 6

Value Weighted Market Index Cumulative Average Returns (2001-2004)

All Figures Are In Percentages Unless Otherwise Indicated. Firms Are Presented Alphabetically

\begin{tabular}{cccc}
\hline Company Name & 4 Year Returns & $\begin{array}{c}\text { 4 Year Value Weighted } \\
\text { Market Return }\end{array}$ & $\begin{array}{c}\text { 4 Year Excess Returns } \\
\text { (Return - Market) }\end{array}$ \\
\hline AFLAC & 88.91 & 24.73 & 64.18 \\
Amgen & 123.18 & 24.73 & 98.45 \\
CDW & $(96.23)$ & 24.73 & $(120.96)$ \\
Cisco Systems & 9.17 & 24.73 & $115.56)$ \\
Four Seasons & 144.09 & 24.73 & 176.90 \\
Genentech & 201.63 & 24.73 & 123.19 \\
Intuit & 147.92 & 24.73 & 16.65 \\
Microsoft Corporation & 41.38 & 24.73 & 330.70 \\
Network Appliance & 355.43 & 24.73 & 67.07 \\
Nordstrom & 91.80 & 24.73 & 383.79 \\
QUALCOMM & 408.52 & 24.73 & 90.91 \\
SRA International & 115.64 & 24.73 & 179.46 \\
Starbucks & 204.19 & 24.73 & 209.47 \\
Timberland & 234.20 & 24.73 & 181.59 \\
Valero Energy Corporation & 206.32 & 24.73 & 163.15 \\
Whole Foods & 187.88 & 24.73 & $\mathbf{1 2 9 . 2 7}$ \\
Cumulative Average & $\mathbf{1 5 4 . 0 0}$ & & $\mathbf{3 2 . 3 2}$ \\
Returns & & & \\
Annualized Returns & $\mathbf{3 8 . 5 0}$ & & \\
\hline
\end{tabular}


Table 7

Event And Matched Market Return

All Figures Are In Percentages Unless Otherwise Indicated. Firms Are Presented Alphabetically

Four Year Holding Period Returns

\begin{tabular}{|c|c|c|c|}
\hline Diversity Portfolio (1) & Market Index (2) & Buy And Hold Excess Returns (1 -2 ) & Market Index Type \\
\hline 96.78 & 4.17 & 92.61 & Value Weighted \\
\hline 96.78 & $(0.03)$ & 96.81 & Large Capitalization \\
\hline
\end{tabular}

NOTES 
NOTES 